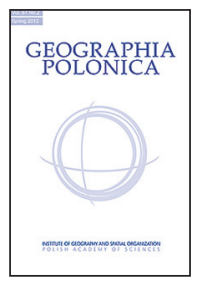 \\ INSTITUTE OF GEOGRAPHY AND SPATIAL ORGANIZATION \\ POLISH ACADEMY OF SCIENCES \\ www.igipz.pan.pl \\ www.geographiapolonica.pl
}

\title{
THE FIRST MEDIUM-SCALE TOPOGRAPHIC MAP OF GALICIA (1779-1783) - SURVEY, AVAILABILITY AND IMPORTANCE
}

\section{Paweł Prokop}

Institute of Geography and Spatial Organization

Polish Academy of Sciences

Św. Jana 22, 31-018 Kraków: Poland

e-mail: pawel@zg.pan.krakow.pl

\begin{abstract}
Known in Poland as the "Mieg Map", the first topographic map of Galicia, at a scale of 1:28,800 represented one result of The First Military Survey of the Habsburg Empire in the late 18th century. This paper discusses the history of that survey in brief, and describes the map's content and first edition in Poland. Attention is also paid to the Galicia map's status as a unique historical source suitable for GIS analysis and evaluation of developmental trends in the landscape.
\end{abstract}

\section{Key words}

landscape changes $\bullet$ land use $\bullet$ historical maps $•$ GIS

\section{The First Military Survey of the Habsburg Monarchy}

In 1763, defeat in the Seven Years War against Prussia (1756-1763) prompted Empress Maria Theresa of the Habsburg Monarchy to commission reliable maps for the Austrian Army (Kretschmer \& Riedl 2008). As a result, the freshly-reorganised General Staff started the First Military Survey, originally dubbed the Josephinische Landesaufnahme (Josephinian
Land Survey) because it was finished in the reign of Emperor Joseph II, Maria Theresa's son. Lasting for the 23 years between 1763 and 1787, the survey covered the whole territory of the Habsburg Monarchy $\left(680,887 \mathrm{~km}^{2}\right)$, including such new possessions as Galicia (Fig. 1).

Also known as the Kingdom of Galicia and Lodomeria, this historical and geographical region lies in what is today southern Poland and south-western Ukraine. The region became 
Crown Land of the Habsburg Monarchy as a result of the first partition_of the PolishLithuanian Commonwealth in 1772.

The map of Galicia was compiled on a scale of 1:28,800 (400 fathoms or 400 times $6 \mathrm{ft}$ ) over the 1779-1783 period. In the Polish and Ukrainian reference literature, the term 'Mieg Map' is also in use, after Lt. Col. Friedrich von Mieg, an officer of the General Staff who oversaw this particular survey (Bukowski 2013).

Although the First Military Survey is the focus of this paper, mention is also made of subsequent cartographic efforts. Progress in geodesy, topography and cartography initiated new mapping of the Habsburg Monarchy in the nineteenth century, such as:

- the Second (1806-1869) Military Survey, (Franciscan) with Galicia and Bukovia mapped (in the years 1861-1864) on a scale of $1: 28,800$

- the Third (1869-1887) Military Survey, (Franciscan-Josephine) on the scales 1:25,000 and $1: 75,000$

- the Fourth (1896-1915) Military Survey, as suspended due to World War I (Kretschmer \& Riedl 2008).

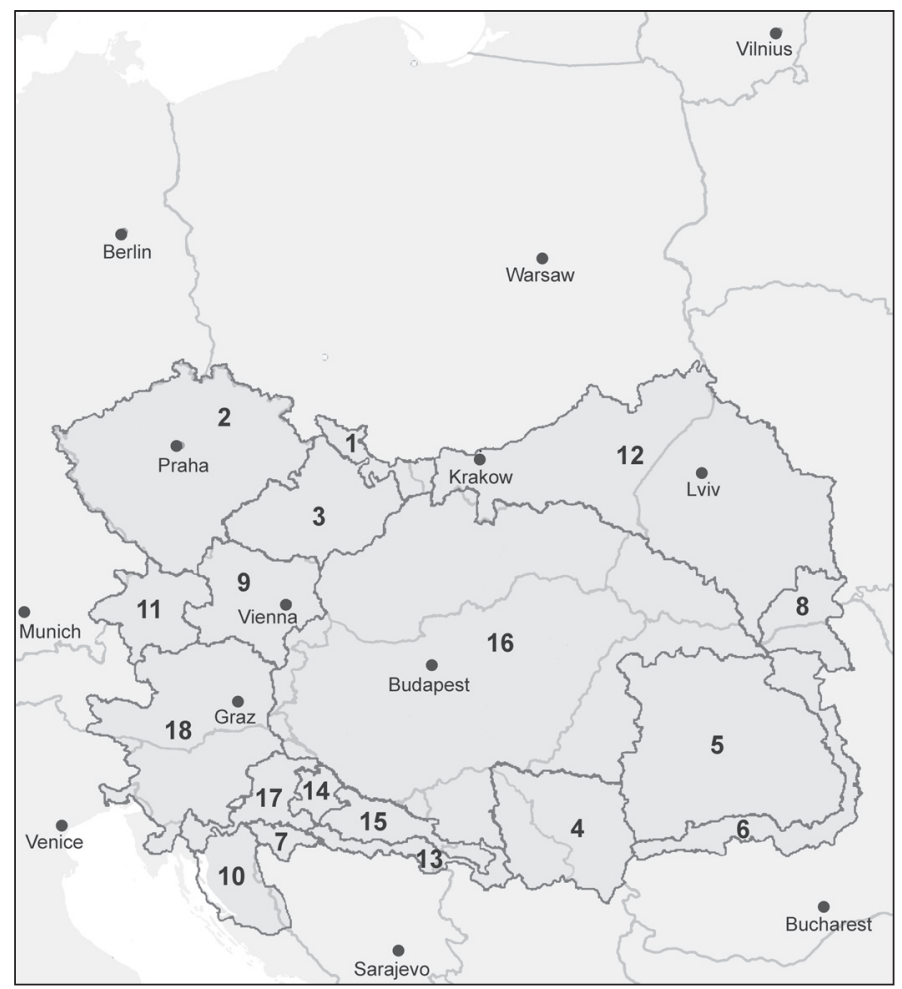

Figure 1. The extent of the First Military Survey in the Middle Europe including Galicia territory. Dark grey lines indicate Habsburg Empire borders, light grey lines indicate present-day international borders Regions and periods of survey: 1 - Silesia 1763, 2 - Bohemia 1764-1767, 3 - Moravia 1764-1768, 4 - Banat 1769-1772, 5 - Transylvania 1769-1773, 6 - Vlach-Banatian Regiment 1773-1774, 7 - Bani Regiment 1773-1775, 8 - Bukowina 1773-1775, 9 - Lower Austria 1773-1781, 10 - Karlovac District 1774 -1775, 11- Upper Austria 1775-1777, 12 - Galicia and Lodomeria 1779-1783, 13 - Slavonian Military Frontier 1780, 14 - Varsadi District 1781-1782, 15 - Slavonia 1781-1783, 16 - Kingdom of Hungary 1782-1785, 17 - Croatia 1783-1784, 18 - Middle Austria 1784-1787

Source: based on Mapire http://mapire.eu/en, Molnar et al. 2014, Arcanum Adatbázis Kft, Österreichisches Staatsarchiv in Vienna. 
In contrast to the First Military Survey, all subsequent surveys were based on a network of horizontal control points (triangulation); and the maps have cartographic projections.

\section{The discovery of the Galicia map's content}

On account of its military significance, the Josephinian Map of Galicia long remained secret. Descriptions only appeared in 1864, while the work did not gain its first public presentation until the time of the World Exhibition staged in Vienna in 1873 (Roskiewicz 1873). In turn, the circumstances behind the map's origin and the survey procedure were first described by Josef Paldus, a Czech Colonel in the Austro-Hungarian Army and later military historian of the Austrian State Archives (Österreichisches Staatsarchiv) in Vienna. According to him, the First Survey of the Habsburg Monarchy resulted in 3589 handdrawn coloured map sheets measuring approximately 61 by $42 \mathrm{~cm}$ (Paldus 1919). The Galicia and Lodomeria Map is composed of 413 sheets. These were drawn in two sets - an original and two copies of fair quality. The survey was not based on any network of precisely defined triangular points, though the military men were educated in surveying and cartography. Most of the details were mapped with the unaided eye, and their quality depends on the experience of the cartographer, the variety of landscape characteristics, etc. The generalisation methods are mostly unknown and varied, but very likely depended on the importance of a particular feature or object from the military point of view. The map was supplemented by six volumes including descriptions containing certain information not forming part of the map sheets. Special attention was paid to transport and communications (surfaces of roads and their capacity to carry traffic), rivers, streams and artificial gullies (width and depth), land use (arable fields, hayfields, pastures, etc.) and various types of building - castles, churches, mills, etc., given that all of these may assume military significance.
Just after World War I, Ludomir Sawicki, Professor of Geography at the Jagiellonian University, led extensive document searches at the Vienna Archives. As the delegate of the Polish Liquidation Committee acting under the Treaty of St. Germain (signed in 1919), he was obliged to determine the Polish claim to the cultural and scientific output of the former Habsburg Monarchy. L. Sawicki drew up a list of maps concerned with the territory of the newly-established Poland, and thereby published information on the Galicia map (Sawicki 1920). The map was not covered by revindication at that time. At the exhibition of maps held on the occasion of the Seventh International Historical Congress convened in Warsaw in 1933, the Austrian Military Archives in Vienna showed a general map from the First Survey, but only at a general scale of 1:2,500,000 (von Nischer-Falkenhof 1937). Before World War II, the National Library of Warsaw imported black and white reproductions of the Galicia map at a scale of 1:28,800 (Bukowski 2013). Despite the poor quality of the copies and the lack of map descriptions, these are used by Polish scientists through to the present day. The Galicia map was never in fact printed, and the original manuscripts are stored in the Austrian State Archives, in the Map Collection of its Military Archives Department in Vienna, sign. BIXa.390.

\section{The Polish edition of the Galicia map from the First Military Survey}

The scientific community in various countries once belonging to the Habsburg Monarchy was aware of the First Survey's importance, and has made efforts to prepare original maps for publication in traditional and/or digital format (see for instance maps for Slovenia: Rajšp 1996, Hungary: Az első katonai felmérés... 2004, Czech Republic: http://oldmaps.geolab. cz, Belgium: http://belgica.kbr.be/fr/coll/cp/ cpFerraris_fr.html). In Poland, the map is being prepared for printing as a joint project of historians from the Institute of History of the Polish Academy of Sciences (PAS), the Institute 
of Archaeology and Ethnology PAS, the PAS Scientific Centre in Vienna, the Pedagogical University of Kraków, and the University of Rzeszów (Bukowski \& Janeczek 2013).

The map sheets covering the territory of the Kingdom of Galicia and Lodomeria were in fact divided between fifteen volumes. The printing of the first seven volumes covering most of the area falling within Poland has been enabled by the National Programme for the Development of the Humanities (Bukowski 2013). Thus far, the first four volumes have been printed, with a further description of their content made on the basis of Volume 2 as an example (Bukowski et al. 2013b). Each volume is composed of two parts (subvolumes) $A$ and $B$. Part $A$ includes map-sheet descriptions in German, with a parallel translation into Polish, as well as several papers (Tab. 1). The editorial note describes the history of research on the Galicia map briefly, along with the approaches taken to the Polish edition, as well as national editions of the First Military Survey maps in other countries of the former Habsburg Monarchy (Bukowski et al. 2013a). The next paper deals with the history of military cartography of the Habsburg Monarchy between the late 18th and early 20th centuries (Konias 2013). We here receive information as to the methods of survey, the content of the map, and its accuracy. The second paper contains editorial remarks about the area covered by the Galicia map and its detailed history, applied editorial rules for map sheets and their description during printing (Bukowski et al. 2013a). Also very helpful for geographers is the next paper, which shows the symbols and map captions prepared by the editors (Janeczek 2013). This is especially important as the original map legend was never formalised. Moreover, Part A includes the list of abbreviations, commentaries to the descriptions, an inventory of names included on the map, as well as an index of maps and descriptions. Part B in turn has facsimiles prepared from the original hand-drawn map sheets and, for comparison, also some facsimiles prepared from hand-drawn copies.

\section{The Galicia map and GIS}

The usability of the First-Survey maps could be improved significantly by georeferencing, to allow for more sophisticated spatial analyses in geographical information systems (GIS), in combination with the other data sets. The Hungarian firm Arcanum Ltd. (Timar et al. 2006a; http://www.arcanum.hu) provides access to georeferenced map sheets scanned from the Austrian State Archives in Vienna through the Mapire webpage (Biszak et al. 2014; http://mapire.eu/en). Despite the lack of a coordinate system for the First Survey, the high accuracy of the map sheets has allowed for its georeferencing with an error of 100-200 m (Molnar et al. 2014).

Table 1. Example of the Stary Sacz town description from Section 43 of the Galicia map from the First Military Survey (see Fig. 2, upper map sheet). Similar detailed descriptions were applied to all small localities, such as Podegrodzie, Wyglanowice, Mostki, etc.

\begin{tabular}{|l|l|}
\hline $\begin{array}{l}\text { Distances (in hours of march) } \\
\text { Watid constructions }\end{array}$ & $\begin{array}{l}\text { Podegrodzie } 3 / 4, \text { Wyglanowice } 1 / 2, \text { Mostki } 1 / 2 \\
\text { nunnery, parish church, Franciscan monastery are solid buildings } \\
\text { Stream going from Moszczenica creates in the valley a number of ponds } \\
\text { with drinkable water and falls into the Poprad here connecting with the River } \\
\text { Dunajec } \\
\text { Forests }\end{array}$ \\
Roads & $\begin{array}{l}\text { Elevation towards Moszczenica is mostly overgrown with high forest } \\
\text { The national road to Nowy Sacz is good; besides all the other roads have } \\
\text { sountains }\end{array}$ \\
& $\begin{array}{l}\text { Last slope near the folwark (serfdom-based farm) dominates the surrounding } \\
\text { countryside }\end{array}$ \\
\hline
\end{tabular}

Source: after Bukowski et al. 2013b. 

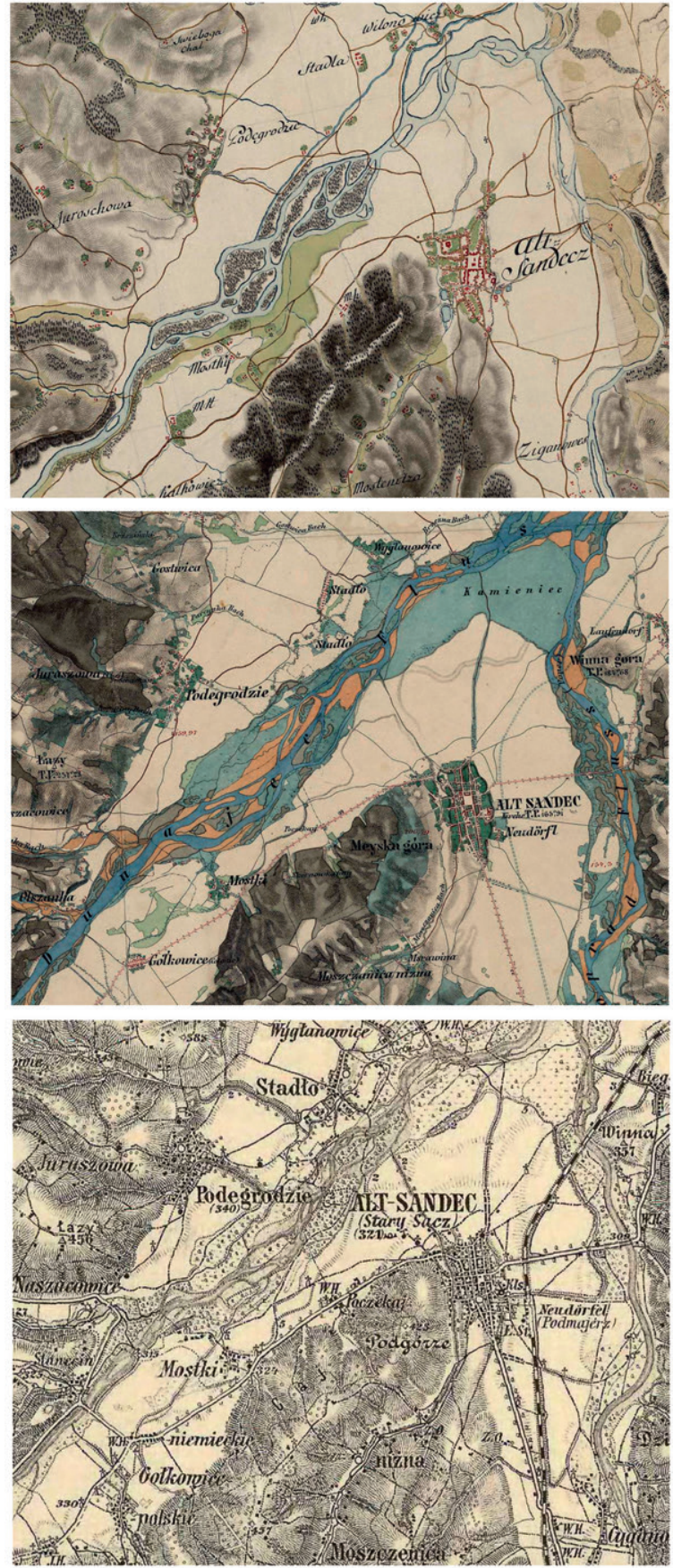

Figure 2. The vicinity of Stary Sacz on the map of Galicia from the First Military Survey (upper sheet $1: 28,800$ ), the Second Military Survey (middle sheet 1:28,800) and the Third Military Survey (lower sheet $1: 75,000)$

Source: based on Mapire (http://mapire.eu/en), Arcanum Adatbázis Kft, Molnar et al. 2014. Image courtesy Österreichisches Staatsarchiv in Vienna. 
The current version of Mapire contains maps of the First and Second Military Surveys scaled to $1: 28,800$ and covering the entire Habsburg Empire (Tima et al. 2006b). The Third Military Survey is in turn available on scales of 1:75,000 for the whole Empire, as well as 1:25,000 in the case of the Hungarian Kingdom (Molnar \& Timar 2009). The latter also covers a part of the southern Poland. The Mapire webpage enables the user to navigate historical maps of the Habsburg Empire, including via Here Maps (Aerial) and OpenStreetMap. The technology allows the two maps from different periods to be browsed in a synchronised view, as well as with a $3 \mathrm{D}$ view applied. Moreover, the purchasing of prints or digital copies of a map is possible, sheet by sheet, from the Austrian State Archives in Vienna, through its webpage.

\section{The importance of the first medium-scale topographic map of Galicia}

There is no doubt that the first Polish edition of the coloured map of Galicia (1779-1783) is the source of variable information, not available over the last 250 years. However the importance of this map lies, not only in its moredetailed scale and military-topographical descriptions, as compared with previous surveys, but also in its period of origin. The map records the state of the geographical environment with some features from the late Middle Ages preserved, given that it still predates the far-reaching economic and social transformations related to the Industrial Revolution. For these reasons, the map of Galicia is of great use in historical, archaeological, ecological and onomastic research (Konias 2000, 2013; Tikhoonova 2016)

For geographers, the Galicia map represents the first significant cartographic source that can be used in multitemporal analysis. It therefore has particular application in studies on land use and land-cover change, past hydrological conditions, cultural landscape evolution, urbanisation, and human-activity development, at various scales from the local to the regional (Petryšyn 2006; Affek 2013, 2014; Łajczak 2016). In Polish conditions, it would seem that the greatest potential for spatial and multitemporal analyses lies in a combination of information from both sources, i.e. the printed map sheets with their descriptions (Bukowski et al. 2013) as well as the already georeferenced digital maps by Arcanum Ltd., available through the Mapire webpage (Biszak et al. 2014).

\section{Editors' note:}

Unless otherwise stated, the sources of tables and figures are the authors', on the basis of their own research. 


\section{References}

AfFEK A., 2013. Georeferencing of historical maps using GIS, as exemplified by the Austrian Military Surveys of Galicia. Geographia Polonica, vol. 86, no. 4, pp. 375-390.

Affek A., 2014. Landscape continuity versus landscape transformation: A case study in the Wiar River catchment, Polish Carpathians (17802000). Problemy Ekologii Krajobrazu, vol. 30, no. 30, pp. 147-155.

Az elsó katonal felmérés - Magyar Királyság, 2004. Budapest (DVD issue).

Biszak E., Kulovits H., Biszak S., Timár G., Molnár G., Székely B., Jankó A., Kenyeres I., 2014. Cartographic heritage of the Habsburg Empire on the web: The MAPIRE initiative. 9th International Workshop on Digital Approaches to Cartographic Heritage Budapest, 4-5 September 2014, At 26-31, vol. 9.

BUKOWSKI W., 2013. Galicia on the Josephine topographic map 1779-1783, vol. 1-15., Annual Report Polish Academy of Sciences. Wrocław: Polish Academy of Sciences, pp. 40-42.

Bukowski W., Dybaś B., Noga Z., 2013a. Galicja na józefińskiej mapie topograficznej z lat 1779-1783. Uwagi edytorskie [in:] W. Bukowski, B. Dybaś, Z. Noga (eds.), Galicja na józefińskiej wojskowej mapie topograficznej 1779-1783, vol. 2, part A, Kraków: Wydawnictwo Societas Vistulana, Instytut Historii PAN Stacja Naukowa w Wiedniu, Instytut Historii Uniwersytet Pedagogiczny w Krakowie, pp. XLVII-LXX.

Bukowski W., Dybaś B., Noga Z. (eds.), 2013 b. Galicja na józefińskiej wojskowej mapie topograficznej 1779-1783. Vol. 2, part A and part B, Kraków: Wydawnictwo Societas Vistulana, Instytut Historii PAN Stacja Naukowa w Wiedniu, Instytut Historii Uniwersytet Pedagogiczny w Krakowie.

Bukowski W., JaneCzeK A., 2013. Mapa józefińska Galicji (1779-1783) w przededniu edycji. Przedmiot i założenia programu wydawniczego. Studia Geohistorica, no. 01, pp. 91-112.

JANECZEK A., 2013. Znaki i napisy objaśniajace zdjęcia józefińskiego Galicji [in:] W. Bukowski, B. Dybaś, Z. Noga (eds.), Galicja na józefińskiej wojskowej mapie topograficznej 1779-1783, vol. 2, part A, Kraków: Wydawnictwo Societas Vistulana, Instytut Historii PAN Stacja Naukowa w Wiedniu, Instytut Historii Uniwersytet Pedagogiczny w Krakowie, pp. LXXI-XCI.
KONIAS A., 2000. Kartografia topograficzna Śląska Cieszyńskiego i zaboru austriackiego od II połowy XVIII wieku do poczq̨tku XX wieku. Katowice: Wydawnictwo Uniwersytetu Ślaskiego.

Konias A., 2013. Pierwsze wojskowe zdjęcie topograficzne Galicji z okresu józefińskiego [in:] W. Bukowski, B. Dybaś, Z. Noga (eds.), Galicja na józefińskiej wojskowej mapie topograficznej 1779-1783, vol. 2, part A, Kraków: Wydawnictwo Societas Vistulana, Instytut Historii PAN Stacja Naukowa w Wiedniu, Instytut Historii Uniwersytet Pedagogiczny w Krakowie, pp. XXXI-XLVI.

ŁAUCZAK A., 2016. Zarys historii działalności gospodarczej w masywie Babiej Góry i otaczajacym terenie (Zachodnie Karpaty). Przegląd Geograficzny, vol. 88, no. 1, pp. 5-30.

MOKRE J., 2013. Kartografia wojskowa monarchii austriackiej do końca XVIII wieku oraz rzut oka na wiek XIX i poczatek XX stulecia [in:] W. Bukowski, B. Dybaś, Z. Noga, (eds.), Galicja na józefińskiej wojskowej mapie topograficznej 1779-1783, vol. 2, part A, Kraków: Wydawnictwo Societas Vistulana, Instytut Historii PAN Stacja Naukowa w Wiedniu, Instytut Historii Uniwersytet Pedagogiczny w Krakowie, pp. XV-XXXVIII.

MolnÁR G., TimÁr G., 2009. Mosaicking of the 1:75,000 sheets of the Third Military Survey of the Habsburg Empire. Acta Geodaetica et Geophysica Hungarica vol. 44, no. 1, pp. 115-120.

Molnár G., Timár G., Biszak E., 2014. Can the First Military Survey maps of the Habsburg Empire (1763-1790) be georeferenced by an accuracy of 200 meters? [in:] Conference: 9th International Workshop on Digital Approaches to Cartographic Heritage Budapest, pp. 4-5.

Paldus J., 1919. Die militärischen Aufnahmen im Bereiche der Habsburgischen Länder aus der Zeit Kaiser Josephs II.: ausgeführt durch den K.K. Generalquartiermeisterstab in den Jahren 1763-1785. Ein Beitrag zur historischen Landeskunde. Wien: Alfred Hölder.

Petry̌̌Yn H., 2006. "Karta F. fon Miga" (1779-1782) jak džerelo do mistoznavstva Halyčyny. Lviv: Lvivska Politekhnika,

RAš̌p. V., 1996. Slovenija na vojaškem zemljevidu 1763-1787 - Maps. Josephinishe Landesaufnahme 1763-1787 für das Bebiet der Republik Slowenien - Karten. Ljubljana: ZRC SAZU.

RoskIEWICZ J., 1873. Kartographie [in:] W.F. Exner (ed.), Weltausstellung 1873 in Wien. Beiträge zur 
Geschichte der Gewerbe und Erfindungen Oesterreichs von der Mitte des XVIII. Jahrhunderts bis zur Gegenwart, vol. 2, Wien: Braumüller.

SAWICKI L., 1920. Spis map Archiwum Wojennego w Wiedniu odnoszacych się do ziem polskich. Warszawa: Główna Księgarnia Wojskowa.

TIKHOONOVA O., 2016. Reading the history of bastion castles in Galicia (Eastern Europe) using the Friedrich Von Mieg map. WIT Transactions on The Built Environment, vol. 158, pp. 73-84.

Timár G., Biszak S., Székely B., Molnár G., 2006a. Digitized maps of the Habsburg Military Surveys: Overview of the project of ARCANUM Ltd. (Hungary) [in:] M. Jobst (ed.), Preservation in digital cartography. Lecture Notes in Geoinformation and Cartography, Berlin-Heidelberg: Springer, pp. 273-283.
Timár G., Molnár G., Székely B., Biszak S., VarGA J., JANKÓ A., 2006b. Digitized maps of the Habsburg Empire - The map sheets of the second military survey and their georeferenced version. Budapest: Arcanum.

VON Nischer-FalKenhof E., 1937. The survey by the Austrian general staff under the empress Maria Theresa and the emperor Joseph II, and the subsequent initial surveys of neighbouring territories during the years 1749-1854. Imago Mundi, vol. 2, no. 1, pp. 83-88.

\section{Online sources}

http://belgica.kbr.be/fr/coll/cp/cpFerraris_fr.html

[15 December 2016].

http://mapire.eu/en [15 December 2016].

http://oldmaps.geolab.cz [15 December 2016].

http://www.arcanum.hu [15 December 2016]. 